\title{
Botrytis cinerea is the causal agent of post-harvest grey mould rot on green bean (Phaseolus vulgaris) in Korea
}

\author{
Md. Aktaruzzaman ${ }^{1,2}$ (D) Tania Afroz ${ }^{3} \cdot$ Young-Gyu Lee $^{2} \cdot$ Byung-Sup Kim $^{3}$
}

Received: 19 April 2017 / Accepted: 19 July 2017 / Published online: 25 July 2017

(C) Australasian Plant Pathology Society Inc. 2017

\begin{abstract}
In May 2016, an occurrence of grey mould rots was observed on harvested green bean pods after 3-5 days of storage in refrigerator in Gangneung, Gangwon Province, South Korea. The symptoms observed were water-soaked grey lesions with white to greyish mycelium on infected pods. The fungus was isolated from infected pods and cultured on potato dextrose agar (PDA). For identification of the fungus, we examined morphology, sequenced a portion of the rDNA and three nuclear protein coding genes and confirmed its pathogenicity according to Koch's postulates. The results of morphological examinations, pathogenicity tests and DNA revealed that the causal agent was Botrytis cinerea. This confirms postharvest grey mould rot of green bean in Korea.
\end{abstract}

Keywords Botrytis cinerea - Green bean - Grey mould rot . Phaseolus vulgaris $\cdot$ Post-harvest

Green bean (Phaseolus vulgaris) is an economically important food crop worldwide under the legume family Fabaceae. Generally, green mature pods are cooked and eaten as a vegetable, but immature pods are marketed as fresh, frozen, or canned, whole or cut. Botrytis cinerea (teleomorph Botryotinia fuckeliana) is a filamentous fungal pathogen with

Md. Aktaruzzaman

jewellhstu.plp@gmail.com

1 East Coast Life Science Institute, Gangneung-Wonju National University, Gangneung 25457, Republic of Korea

2 National Institute of Crop Science, Highland Agriculture Research Institute, Rural Development Administration, Daegwallyeong, Pyeongchang 25342, Republic of Korea

3 Department of Plant Science, Gangneung-Wonju National University, Gangneung 25457, Republic of Korea a broad host range (more than 200 species) that causes grey mould rot disease on a variety of dicotyledonous plants, including many vegetables, fruits, ornamental flowers, and greenhouse plants (Elad 1997; Jarvis 1977). The pathogen is a necrotroph, inducing host cell death resulting in serious damage to plant tissues culminating in rot of the plant (Govrin and Levine 2000; Dean et al. 2012). Botrytis spp. are often considered a cool weather pathogen with best growth, sporulation, spore release, germination, and establishment of infection occurring at an optimum of 18 to $23^{\circ} \mathrm{C}$. The infections often cannot be detected at harvest but develop rapidly under the moist conditions encountered during storage and transport, even at low temperature as $0{ }^{\circ} \mathrm{C}$ (Romanazzi et al. 2016). In this study, we identified the causal agent of post-harvest grey mould rot of green bean based on morphological characteristics, phylogenetic analysis, and pathogenicity.

In May 2016, an occurrence of grey mould rots was observed on harvested green bean pods after 3-5 days of storage in refrigerator at $4{ }^{\circ} \mathrm{C}$ and $80 \%$ relative humidity in Gangneung, Gangwon Province, South Korea. The symptoms observed were water-soaked grey lesions with white to greyish mycelium on infected pods and finally rotten the pods (Fig. 1a). Diseased tissue was excised and surface sterilized by immersion in $1 \%$ sodium hypochlorite $(\mathrm{NaOCl})$ for $1 \mathrm{~min}$, rinsed three times with sterilized distilled water, placed on potato dextrose agar (PDA, Difco) plates, and incubated at $20 \pm 2{ }^{\circ} \mathrm{C}$. To obtain pure cultures, hyphal tips were excised after 4 days growth and transferred to new PDA media and incubated at $20 \pm 2{ }^{\circ} \mathrm{C}$ for 7 days. A total of six morphologically similar fungal isolates were obtained from six samples of grey moulds of green bean, and of these, isolate GBGM003 was examined for identification. Fungal colonies on PDA at $20{ }^{\circ} \mathrm{C}$ were initially white but turned grey to dark grey with abundant conidia, after 7 days (Fig. 1 c). Conidia $(n=50)$ were 
Fig. 1 Post-harvest grey mould rot on green bean. a Symptoms of post-harvest grey mould rot caused by Botrytis cinerea $\mathbf{b}$ grey mould rot developed 7 days after artificial inoculation c one-weekold colony of $B$. cinerea on potato on PDA d black sclerotia developed on PDA e conidia
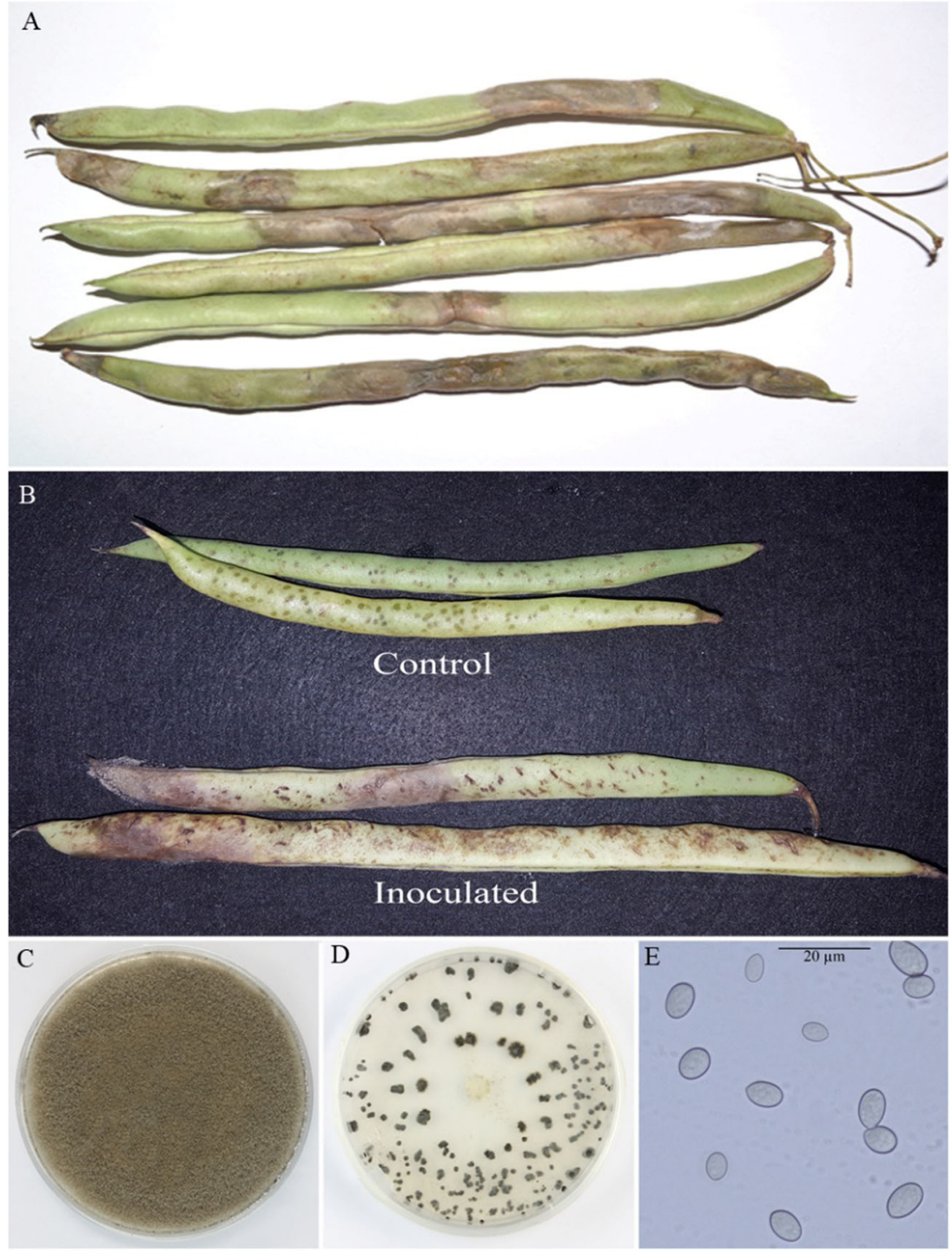

single-celled, ellipsoidal or ovoid, 5.1 to $8.5 \times 5.2$ to $9.8 \mu \mathrm{m}$ on PDA (Fig. 1e). Conidiophores arose singly or in groups, straight or flexuous, septate, with an inflated basal cell and brown to light brown, and measured 12.1-26.3 $\times 109.1-$ $410.5 \mu \mathrm{m}$. After 3 weeks, the fungus formed several black sclerotia ranging from 1.2 to $4.3 \times 1.1$ to $3.5 \mathrm{~mm}(n=20)$ near the edge of the Petri dish (Fig. 1d). The morphological characteristics of the identified species are summarized in Table 1. A representative isolate (GBGM003) was deposited in Korean Agricultural Culture Collection, National Institute of Agricultural Science, Rural Development Administration, Wanju, South Korea (KACC48151), to be used for further studies.

To conduct the pathogenicity test, inoculums was prepared by harvesting conidia from 2 -week-old cultures on PDA. A conidial suspension $\left(1 \times 10^{6}\right.$ conidia/ml $)$ was sprayed onto two young pods that were wounded by piercing with a sterilized needle. Another two wounded pods were sprayed with sterilized water, serving as controls. Inoculated all pods were placed on moist filter papers in a plastic box and incubated in a growth chamber at $20{ }^{\circ} \mathrm{C}$ and $90 \pm 10 \%$ relative humidity. Five days after inoculation, water-soaked lesions with grey conidia developed on inoculated pods, whereas control pods were symptomless (Fig. 1b). The pathogenicity test was repeated with similar results. The pathogen was successfully reisolated from inoculated pods, fulfilling Koch's postulates.

Genomic DNA of isolated fungus was extracted using DNeasy Plant Mini Kit (Qiagen Inc., Valencia, CA, USA) following the manufacturer's instructions. DNA sequence of internal transcribed spacers (ITS1 \& ITS2) and 5.8S ribosomal DNA and the three nuclear protein-coding genes glyceraldehyde-3- phosphate dehydrogenase gene (G3PDH), heat-shock protein 60 gene $(H S P 60)$ and DNA-dependent RNA polymerase subunit II gene $(R P B 2)$ were amplified using primer pairs ITS 1 (5'-TCCGTAGGTGAACC TGCGG- 3')/ITS4 (5'-TCCTCCGCTTATTGATATGC-3') 
Table 1 Morphological characteristics of the grey mould rot fungus isolated from green bean

\begin{tabular}{llll}
\hline Characteristic & & Present isolate & Botrytis cinerea $^{\text {a }}$ \\
\hline Colony & Color & Initially white and turned grey to dark grey & Grey to greyish brown \\
Conidia & Shape & Ellipsoidal or ovoid & Ellipsoidal or ovoid \\
& Size $(\mu \mathrm{m})$ & 5.1 to $8.5 \times 5.2$ to 9.8 & 6.0 to $18.0 \times 4.0$ to 11.0 \\
& Color & Dark brown & Pale brown \\
Conidiophore & Size $(\mu \mathrm{m})$ & 12.1 to $26.3 \times 109.1$ to 401.5 & 16 to 30 \\
Sclerotia & Shape & Flat or irregular & Flat or irregular \\
& Size & 1.2 to $4.3 \times 1.1$ to 3.5 & - \\
& Color & Black & Black \\
\hline
\end{tabular}

${ }^{\text {a }}$ Described by Ellis and Waller 1974

(White et al. 1990), G3PDH-F (5'-ATTGACATCGTCGC TGTCAACGA-3')/G3PDH-R (5'-ACCCCACTCGTTGT CGTACCA-3'), HSP60-F (5'-CAACAATTGAGATT TGCCCACAAG-3')/HSP60-R (5'-GATGGATCCAGTGG TACCGAGCAT-3') and RPB2-F (5'-GATGATCGTGATCA TTTCGG-3')/RPB2-R (5'-CCCATAGCTTGCTTACCCAT3') (Staats et al. 2005), respectively. The polymerase chain reaction $(\mathrm{PCR})$ was performed in a $25 \mu \mathrm{L}$ reaction mixture containing $0.5 \mu \mathrm{L}$ of each primer $(10 \mathrm{pmol} / \mathrm{L}), 0.5 \mu \mathrm{L}$ of Taq DNA polymerase (Bioneer, Korea), $0.5 \mu \mathrm{L}$ of each dNTP $(10 \mathrm{mM}), 2.5 \mu \mathrm{L}$ of $10 \times$ PCR reaction buffer, $18.5 \mu \mathrm{L}$ of distilled water, and $2.0 \mu \mathrm{L}$ of template DNA. The reaction was performed in Mastercycler Gradient (Eppendorf, Germany). The following thermo cycling pattern was used to amplify ITS region: an initial preheat at $94{ }^{\circ} \mathrm{C}$ for $4 \mathrm{~min}$, followed by 35 cycles of denaturation at $94{ }^{\circ} \mathrm{C}$ for $35 \mathrm{~s}$, annealing at $52{ }^{\circ} \mathrm{C}$ for $55 \mathrm{~s}$, and extension at $72{ }^{\circ} \mathrm{C}$ for $1 \mathrm{~min}$, terminating with a final extension at $72{ }^{\circ} \mathrm{C}$ for $10 \mathrm{~min}$. The
PCR cycle conditions were $94{ }^{\circ} \mathrm{C}$ for $5 \mathrm{~min}$, followed by 35 cycles of $94{ }^{\circ} \mathrm{C}$ for $30 \mathrm{~s}, 55^{\circ} \mathrm{C}$ for $30 \mathrm{~s}, 72{ }^{\circ} \mathrm{C}$ for $90 \mathrm{~s}$ and a final elongation step at $72{ }^{\circ} \mathrm{C}$ for $10 \mathrm{~min}$ for $H S P 60$ and $R P B 2$ gene segments. The same program with an annealing temperature of $64{ }^{\circ} \mathrm{C}$ was applied to amplify the $G 3 P D H$ gene. The obtained nucleotide sequences were searched by using BLASTn available from the GenBank database (http:// www.ncbi.nlm.nih.gov/BLAST/). Phylogenetic analysis was performed by using the MEGA6 program (Tamura et al. 2013) with the neighbor-joining method (Saitou and Nei 1987).

BLAST analysis of the resulting approximately 500-bp rDNA sequence, 883-bp G3PDH sequence, 1015-bp HSP60 sequence and 1093-bp RPB2 sequence were obtained. The sequences for the representative isolate GBGM003 have been deposited in the NCBI database (GenBank accession no. KY070583 for ITS-5.8S rDNA, KY070584 for G3PDH, KY070585 for HSP60, and KY070586 for RPB2). Blast analysis showed that the $r D N A, G 3 P D H$ and HSP60 sequences of
Fig. 2 Phylogenetic analysis of Botrytis cinerea isolate GBGM003, constructed by using the neighbor-joining method based on combined $r D N A$, G3PDH, HSP60 and RPB2 gene sequence data. Monilinia fructigena strain 9201 was used as the out group. The numbers at the nodes indicate bootstrap values from a test of 1000 replicates. The scale bar indicates the number of nucleotide substitutions

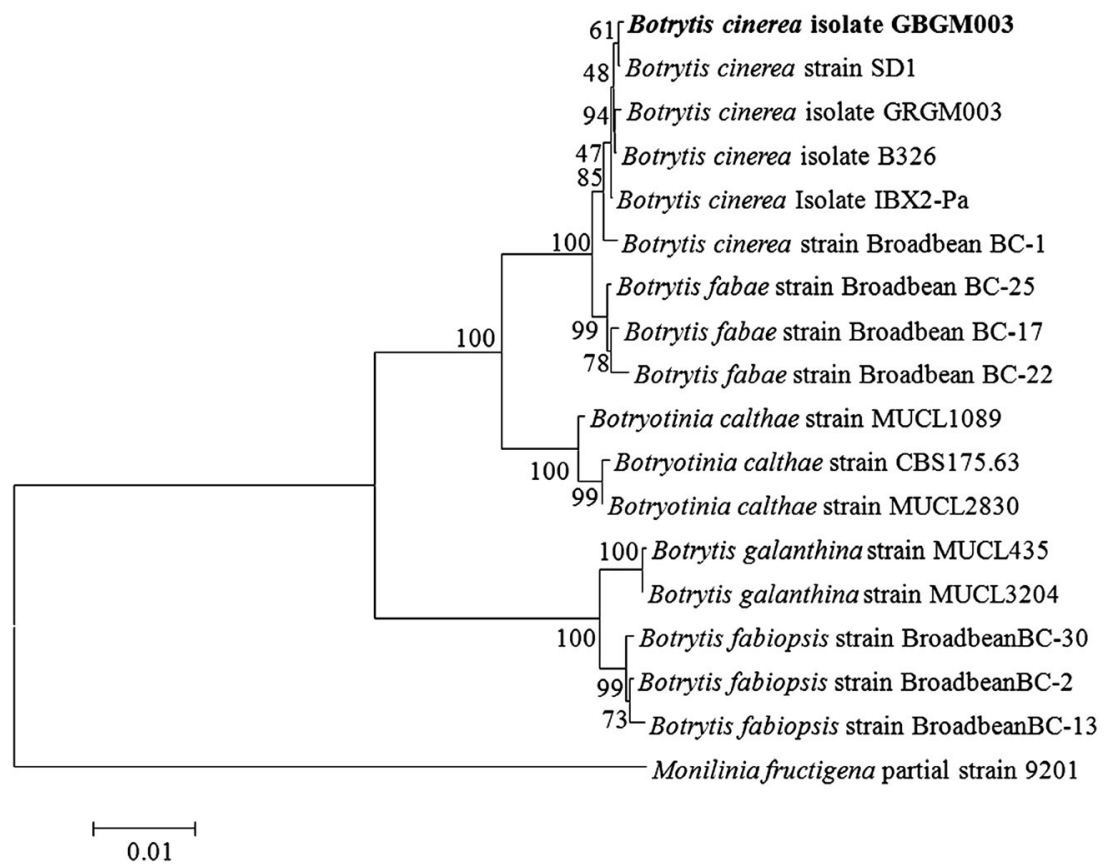


isolate GBGM003 were identical to those of $B$. cinerea accession numbers KP255842, KF015583 and KM016534, respectively. The RPB2 sequence from isolate GBGM003 was $99 \%$ similar to $B$. cinerea reported on GenBank (accession number KF857477). In the phylogenetic tree based on combined $r D N A, G 3 P D H, H S P 60, R P B 2$ sequences, the representative isolate was placed within a clade comprising reference isolates of $B$. cinerea (Fig. 2).

Based on symptoms, a morphological characteristic, phylogenetic analysis and pathogenicity, this fungus was identified as B. cinerea (Ellis 1971; Ellis and Waller 1974; Barnett and Hunter 1972; Zhang 2006). This fungus has been reported on leaves and/or pods infected in field conditions in different countries, such as Bulgaria, China, Canada, Korea and New Zealand (Farr and Rossman 2017), but has not been reported in Korea as a post-harvest pathogen. This study demonstrates that $B$. cinerea is a causal agent of post-harvest grey mould rot of green bean in Korea.

Acknowledgments This research was supported by Golden Seed Project Grant (213001-04-4-SB630), Ministry of Agriculture, Food and Rural Affairs (MAFRA), Ministry of Oceans and Fisheries (MOF), Rural Development Administration (RDA) and Korean Forest Service (KFS), South Korea.

\section{References}

Barnett HL, Hunter BB (1972) Illustrated genera of imperfect fungi. Burgess Publishing Company, Minneapolis

Dean R, van Kan JA, Pretorius ZA, Hammond-Kosack KE, Di Pietro A, Spanu PD (2012) The top 10 fungal pathogens in molecular plant pathology. Mol Plant Pathol 13:414-430
Elad Y (1997) Effect of filtration of solar light on the production of conidia by field isolates of Botrytis cinerea and on several diseases of greenhouse-grown vegetables. Crop Prot 16:635-642

Ellis MB (1971) Dematiaceous hyphomycetes. Commonw. Mycol. Inst, Kew

Ellis MB, Waller JM (1974) Sclerotinia fuckeliana (conidial state: Botrytis cinerea). CMI descriptions of pathogenic fungi and bacteria, No. 431. Commonwealth Mycological Institute, Kew

Farr DF, Rossman AY (2017) Fungal Databases, Syst. Mycol. Microbiol. Lab., ARS, USDA. Retrieved from http://nt.ars-grin.gov/ fungaldatabases/. Accessed 01 May 2017

Govrin E, Levine A (2000) The hypersensitive response facilitates plant infection by the necrotrophic pathogen Botrytis cinerea. Curr Biol 10:751-757

Jarvis WR (1977) Botryotinia and Botrytis species: taxonomy, physiology and pathogenicity. A guide to the literature. Research Branch, Canada Department of Agriculture, Ottawa, p 195

Romanazzi G, Smilanick JL, Feliziani E, Droby S (2016) Integrated management of postharvest gray mold on fruit crops. Postharvest Biol Technol 113:69-76

Saitou N, Nei M (1987) The neighbor-joining method: a new method for reconstructing phylogenetic trees. Mol Biol Evol 4:406-425

Staats M, van Baarlen P, van Kan JAL (2005) Molecular phylogeny of the plant pathogenic genus Botrytis and the evolution of host specificity. Mol Biol Evol 22:333-346

Tamura K, Stecher G, Peterson D, Filipski A, Kumar S (2013) MEGA6: molecular evolutionary genetics analysis Version 6.0. Mol Biol Evol 30:2725-2729

White TJ, Bruns TD, Lee SB, Taylor JW (1990) Amplification and direct sequencing of fungal ribosomal RNA genes for phylogenetics. In: Innis MA, Gelfand DH, Sninsky JJ, White TJ (eds) PCR protocols: a guide to methods and applications. Academic, San Diego, pp 315322

Zhang ZY (2006) Flora fungorum sinicorum. 26. Botrytis, Ramularia. Science Press, Beijing 